John Carroll University

Carroll Collected

Philosophy

$1-15-2006$

\title{
Occupational Safety and Paternalism: Machan Revisited
}

Earl W. Spurgin

John Carroll University, espurgin@jcu.edu

Follow this and additional works at: http:// collected.jcu.edu/phil-facpub

Part of the Ethics and Political Philosophy Commons

\section{Recommended Citation}

Spurgin, Earl W., "Occupational Safety and Paternalism: Machan Revisited" (2006). Philosophy. 9.

http:// collected.jcu.edu/phil-facpub/9

This Article is brought to you for free and open access by Carroll Collected. It has been accepted for inclusion in Philosophy by an authorized administrator of Carroll Collected. For more information, please contact connell@jcu.edu. 


\section{Occupational Safety and Paternalism: Machan Revisited}

In 1987, Machan provided a libertarian case against the right to occupational safety.1 Since before Machan's essay appeared, many business ethicists and legal scholars have given considerable attention, both pro and con, to the overall position Machan endorses: the acceptance of employment at will and the rejection of employee rights.2 No one yet has given adequate attention, however, to the fact that Machan's argument against the right to occupational safety actually stands or falls independently of his overall position on employee rights. I will attempt to do so in this paper.

My analysis of Machan's argument reveals that it ultimately rests on two values: the promotion of employee interests and anti-paternalism. These values, however, often are shared by supporters of the right to occupational safety. Supporters of the right who share these values must find a strategy for opposing Machan's argument that preserves the values. The goal of this paper is to find that strategy. I will begin by demonstrating why Machan's case ultimately rests on the promotion of employee interests and anti- paternalism. Then, I will develop an objection to Machan's argument that preserves those values.

Although my goal is to respond to Machan's argument in a way that is consistent with antipaternalism, I do not seek to respond in a way that is consistent with all the tenets of libertarianism. The reason for this is simple: I am not a libertarian and I reject many of the tenets of libertarianism. For example, for reasons that I will address later in this paper, I reject the libertarian belief that unfettered, free markets will cure society's ills within a time frame required by ethical considerations. Thus, a reader who is looking for a libertarian argument for the right to occupational safety will be disappointed.

A reader who is not a libertarian but is sympathetic to the anti-paternalist position that libertarians adopt, however, may not be so disappointed. I suspect that there are many business ethicists who, like me, are not libertarians, are sympathetic to anti-paternalism, and believe in the employee right to occupational safety. After all, adopting an anti-paternalist position does not commit one to libertarianism. Although John Stuart Mill provides what many consider the seminal defense of anti-paternalism, he is in the liberal tradition rather than the libertarian tradition.3 The argument I will provide falls more in that liberal tradition than in the libertarian tradition.

\section{Machan's argument:}

The first step toward giving Machan's argument against the right to occupational safety the attention it deserves is to recognize that it can be interpreted as two distinct arguments. I will call the first the "general argument" since it draws an entailment from Machan's general position on employee rights. I will call the second the "specific argument" since one could accept it even if one rejects Machan's general position on employee rights.

The general argument:

Machan argues that persons possess only the basic human rights to life, liberty, and property. No other special moral right accrues to any person by virtue of being a member of a specific group.4 Employees, then, have no special rights as employees. They, like the members of any group, have the rights to life, liberty, and property, but no other moral rights.5

This position on rights in general leads to an obvious conclusion regarding the right to occupational safety: It does not exist. The argument is as follows:

(1) There are no special moral rights beyond the basic rights to life, liberty, and property that all persons possess.

(2) The right to occupational safety would be a special moral right.

(3) Therefore, there is no right to occupational safety.

The argument hinges on the success of the first premise. Machan defends the premise by arguing that the enforcement of employee rights impedes free trade in the labor market. He writes,

As individuals who intend to hire out their skills for what they will fetch in the marketplace, $\ldots$ workers have the right to offer these in return for what others ... will offer in acceptable compensation. This 
implies free trade in the labor market. Any interference with such trade ... would violate both the workers' and their traders' human rights.6

An employee right can be enforced only by preventing either employees or employers from making the agreements that they wish to make in free exchanges of labor for compensation.

Essentially, Machan is applying Nozick's theory of distributive justice to the labor market.

Nozick argues that any attempt by government to produce a specific social outcome necessarily will violate the rights of some person or set of persons. He writes,

... no ... distributional patterned principle of justice can be continuously realized without continuous interference with people's lives.... To maintain a pattern one must either continually interfere to stop people from transferring resources as they wish to, or continually (or periodically) interfere to take from some persons resources that others for some reason chose to transfer to them.7

For Machan, employee rights come at the same cost that Nozick attributes to any social outcomes that government might try to bring about: the erosion of someone's freedom. Employers and employees, like all persons, should have equal freedoms. Absent employee rights, Machan argues, they do. The parties are equally free to bargain in an unimpeded labor market in which wages are exchanged for labor. In the course of that bargaining, the parties are free to accept or reject the terms offered. Assuming there is no employment contract to which both parties have agreed, after bargaining has ended and employment has begun, employees are free to quit at any time and employers are free to fire at any time. Enforcing employee rights, on the other hand, destroys this equality of freedoms. When government enforces an employee right, it does so by preventing either employees or employers from making the agreements that they wish both during the pre-employment bargaining period and after employment has begun. For this reason, Machan concludes, employees, like all persons, have only the rights to life, liberty, and property.

Many, however, reject the idea that employees have only the three basic rights that Machan endorses. Although the objections come in various forms, one developed initially by Werhane and later by Werhane and Radin, is especially useful here. 8 Werhane and Radin agree with Machan that equal freedoms for employers and employees is desirable, but, because of the power differences, employee rights are necessary to produce the desired equal freedoms. Without some rights, the more vulnerable positions of employees make them less free than employers. They argue that Nozickian free trade in the labor market ignores the reality of the relation- ships between employees and employers. Under normal circumstances, the relative power differences are too great to conclude that an unimpeded labor market produces equal freedoms for the bargaining parties. They write, "Except under conditions of very low unemployment, employers ordinarily stand in a position of power relative to prospective employees, and most employees, at any level, are replaceable with others.' 9 Given this power differential, the claim that employees and employers are equally free when they bargain in a free labor market unimpeded by employee rights is mistaken. Employees simply lack the power that is necessary to be as free as employers unless they are granted cer- tain rights that lead to more equal grounds on which the parties can bargain.

Some considerations on unemployment and globalization add further support for Werhane's and Radin's position. Since I make use of this line of reasoning when I address the specific argument, I will develop those points later. For now, notice that Werhane and Radin have tailored their position to respond to Machan's general argument. The specific argument provides a rather different challenge that we must explore.

Justification for examination of the specific argument:

Suppose that Werhane's and Radin's objection or some other objection to the first premise of the general argument is decisive. Such an objection proves that employees possess some set of moral rights beyond the basic human rights to life, liberty, and property. Such an objection does not prove, however, that employees possess any specific right $\mathrm{X}$. To prove that right $\mathrm{X}$ is a member of the set of employee rights, one must provide a sound argument for that right.

Typically, to make the case for a set of employee rights, proponents argue for some specific right to demonstrate why they believe employment at will is misguided. For example, Werhane and Radin argue for the right to due process while McCall argues for the right not to be dismissed without just cause.10 No one, however, has made the case against employment at will by arguing for the right 
to occupational safety. Consequently, no one has addressed Machan's specific argument against the right.

This does not mean that no business ethicists support the right to occupational safety. Many do, but they argue for the employee rights to be informed of hazardous working conditions and to refuse hazardous work.11 Arguments for the former right, however, do not address Machan's position at all while arguments for the latter right must respond to the specific argument in order to succeed.

With respect to the right to be informed of hazardous working conditions, there is very little difference between Machan's position and that of those who argue for the right. Machan denies that employees have a right to occupational safety. He does not deny that employees have the right to know that working conditions are unsafe. He writes of instances where employers do not inform employees of dangerous working conditions,

... knowingly or negligently subjecting workers to hazards at the workplace (of which they were not made aware and could not anticipate from reasonable familiarity with the job) constitutes a form of actionable fraud. It comes under the prohibition of the violation of the right to liberty, at times even the right to life. Such conduct is actionable in a court of law and workers ... would be morally justified ... to challenge it.12 In the case of a particular hazard, there may be disagreement between Machan and others over whether it is reasonable to expect employees to anticipate that hazard in the workplace, and such disagreement may result in differing judgments about whether the employer is obligated to inform employees of the hazard. Nevertheless, there is no disagreement over the central point that employees have a right to know that the hazard exists.

The matter is more complicated with respect to the right to refuse hazardous work. Machan describes employees' options in this way:

When prospective employees ... are made aware of the type of job being offered, and its hazards they are at liberty to (a) accept or reject, (b) organize into a group and insist on various terms not in the offing, (c) bargain alone or together with others and set terms that include improvements, or (d) pool work- ers' resources, borrow, and purchase the firm.13

In a trivial sense, Machan's position does not differ from that of his opponents. Clearly, employees can refuse hazardous work. To deny that claim would be to accept a form of slavery. In a more substantive way, however, Machan's position differs dramatically. For Machan, an employer is not obligated to retain the services of a fully informed employee who refuses hazardous work. For his opponents, the fact that dismissal is a possible consequence of refusing hazardous work is tantamount to denying employees the right to refuse the work. To defeat Machan's position, one must provide a convincing case for the right to occupational safety. Only with that right in force can employees refuse hazardous work without opening themselves up to possible dismissal by their employers.14 To accomplish that, however, one must defeat Machan's specific argument against the right to occupational safety.

The specific argument:

The specific argument is based on Machan's anti-paternalism: the view that governments and societies should not control adults for the purposes of promoting the adults' own good. Machan believes that employees are competent adults who are capable of negotiating for themselves the terms of employment. He writes, "My view credits all but the severely incapacitated with the fortitude to be productive and wise when ordering their affairs, workers in- cluded.' 15 The right to occupational safety, Machan argues, is paternalistic because it prevents employees from ordering their affairs as they wish for the purposes of promoting their own good.

This anti-paternalist position on which the specific argument is based applies only to adults.16 Machan recognizes the potential problem raised by children in the workforce. He argues, however, that they have parents or guardians who are morally bound to protect them from dangers such as unsafe working conditions. He writes, "Children ... have rights owed them by their parents. To subject children to hazardous, exploitative work ... could be construed as a violation of their individual rights as young, dependent human beings.' 17 For Machan, children have the rights to life, liberty, and property that all persons have. Since they do not yet have the capacities to make their own decisions regarding how to secure and act on those rights, however, it falls to parents and guardians to make such decisions for them. Parents and guardians must protect children from dangerous work so that 
they can develop their capacities to make their own decisions in the future.

One can glean the specific argument from Machan's example of a coal mining company that lacks the financial resources to operate as safely as its competitors.18 Machan writes, ... suppose that employers are compelled by law to spend the firm's funds to meet safety requirements .... This increased cost of production reduces avail- able funds for additional wages for present and future employees .... This is what has happened: The employee-employer relationship has been unjustly intruded upon, to the detriment not only of mine owners, but also of those who might be employed .... The myth of workers' rights is mostly to blame.19

The most striking feature of this passage is that Machan appeals to the interests of the employees themselves. This does not mean that the interests of employers do not figure in his reasoning. Undoubtedly they do since he supports the basic rights to life, liberty, and property for all persons. His appeal to the interests of employees is striking, however, because he claims that the right to occupational safety actually makes employees worse off than they would be without the right. We rarely think of rights as harmful to us; rather, we think of them as helpful in our attempts to satisfy our needs and wants.

For Machan, the right to occupational safety prevents employees from ordering their working lives as they wish by removing certain options that some employees might choose. The specific argument is as follows:

(1) Paternalism, restricting persons' freedom for their own good, is unjustified.

(2) The right to occupational safety restricts employees' freedom for their own good.

(3) Therefore, the right to occupational safety is unjustified.

Premise 1, Mill, and anti-paternalism:

Essentially, Machan supports premise 1 by adopting Mill's classic opposition to paternalism. For Mill, one is in the best position to determine what is in one's own interests. Mill writes,

... neither one person, nor any number of persons, is warranted in saying to another human creature of ripe years that he shall not do with his life for his own benefit what he chooses to do with it. He is the person most interested in his own well-being: the interest which any other person, except in cases of strong personal attachment, can have in it is trifling compared with that which he himself has; the interest which society has in him individually (except as to his conduct to others) is fractional and altogether indirect, while with respect to his own feelings and circumstances the most ordinary man or woman has means of knowledge immeasurably surpassing those that can be possessed by anyone else.20

Early in this passage, Mill seems to suggest that, close acquaintances aside, one is always the person most concerned with one's own interests. That view, however, is implausible. As Bishop Butler points out, often individuals do not look out for their own interests.21 He writes about individuals, " ... they are often set on work by the particular passions them- selves, and a considerable part of life is spent in the actual pursuit of them, that is, is employed, not by self-love, but by the passions.' $22 \mathrm{He}$ adds, "Men daily, hourly sacrifice the greatest known interest to fancy, inquisitiveness, love, or hatred, any vagrant inclination. The thing to be lamented is not that men have so great a regard to their own good or interest in the present world, for they have not enough ....' 23 Those who abuse dangerous drugs, pursue extreme thrills without taking appropriate care, and otherwise abuse their bodies provide ample evidence for Butler's claim. Given this, Mill seems to base his opposition to paternalism on an implausible premise.

Mill, however, need not, and likely does not, actually hold such an implausible premise. Instead, he need only hold the view that one is more likely to be correct about what is in one's own interests than are others. The remainder of the quoted passage from Mill points in this direction. He claims that while others have only indirect access, one has direct access to one's own needs, wants, and desires. Others who try to dictate one's good generally do so from positions of ignorance. Thus, their judgments about one's good are more likely to be erroneous than are one's own judgments. Mill supports this view further when he writes,

The interference of society to overrule his judgment and purposes in what only regards himself must be grounded on general presumptions which may be altogether wrong and, even if right, are as likely as not to be misapplied to individual cases, by persons no better acquainted with the circumstances of such cases than those are who look at them from with- out.24 
Not only are others more likely to dictate one's good from positions of ignorance, they are more likely to be motivated by concerns other than one's interest. In fact, the remainder of the last sentence quoted from Butler explains why. The entire sentence is as follows: "The thing to be lamented is not that men have so great a regard to their own good or interest in the present world, for they have not enough; but that they have so little to the good of others.' 25 Even though, in a particular case, one may well not be motivated by one's own interest, another person who controls one is even more likely not to be motivated by one's interest.

An example best illustrates what Mill thinks can go wrong when others try to dictate one's own good. There are several academic departments in my institution in which the senior members do not allow untenured members to teach in our freshman seminar. The stated reason is that it is not good for the professional development of the untenured faculty to allow them to teach in an interdisciplinary course outside their areas of specialty. Many untenured faculty in those departments disagree and would like to teach the course. There are good reasons to think that, even though they may get it wrong in particular cases, those untenured faculty are in better positions to know what is their interests regarding the role the freshman seminar can play in their professional development than are the senior faculty who dictate to them what they can and cannot do. They are more likely to know how much they would enjoy and benefit from the freshman seminar and how much that enjoyment and benefit would contribute to their job satisfaction, and, ultimately, their professional development. More- over, they are more likely truly to be motivated by their own interests than are the senior faculty. Despite their stated position, many of those same senior faculty oppose the very notion of a freshman seminar and would like for it be abolished. It is likely that many are motivated by this concern rather than the good of the untenured faculty as they claim.

None of this, however, means Mill believes that those who control others can never truly be motivated solely by a desire to promote the controlled persons' good, nor does it mean that the controlling persons can never be correct about what actually is good for the controlled persons while those they control are incorrect. Instead, Mill believes that competent adults are more likely to get it right about their own interests than are other parties. For that reason, Mill believes we should avoid paternalism.

Premise 2 and Machan's coal mining company example:

Although one can glean Machan's support for premise 2 from his coal mining company example, the example does not highlight the crucial issue of employee options. A modified version of Machan's example better highlights that issue and, consequently, better illustrates how Machan would defend premise 2 .

Suppose the company operates several mines that are all equipped with safety features that meet or exceed government regulations. In addition to the operational mines, the company owns another mine that has not been in operation for decades. Operations in it were suspended at that time because the state of mining technology would not allow the company to extract additional coal even though the company scientists estimated that the reserves were not yet depleted. Suppose, further, that a recent breakthrough in mining technology would allow the company to reopen the mine and extract the remaining reserves. Even with the costs of the new mining equipment, there are enough reserves for the company to turn a profit. Unfortunately, the mine is so far behind the current safety regulations that the company cannot afford to purchase the new mining equipment and update the safety features. Suppose, however, that the company executives determined that the company could afford to purchase the new equipment if it could avoid the costs of updating the safety features by giving employees hazardous-duty pay of twice their normal income to move from the safe mines in which they currently work to the unsafe mine. The right to occupational safety, however, prevents the company from making the offer to employees. If it is to reopen the mine, the company must update the mine so that it meets current safety regulations. This requirement removes the option to work for hazardous-duty pay from employees in order to protect them from unsafe working conditions. Many employees might be willing to take the risk for the additional income, but they will never have that opportunity. 
Machan, moral rights, and legal rights:

Before turning to possible objections to the specific argument, some clarification concerning the distinction between moral and legal rights is necessary. When discussing the right to occupational safety, Machan conflates the moral right and the legal right. He moves easily between the two and treats them almost as though they are one and the same. The moral and legal rights, however, are conceptually distinct. I have a moral right not to have my confidence violated by a friend, but I have no such legal right. Suppose I tell a friend about my infatuation with a mutual acquaintance after securing from the friend a promise not to tell the acquaintance. If the friend breaks that promise, then the friend violates my moral right but violates no legal right. Likewise, one might argue that some rights, such as the right of states to execute criminals, are legal rights with no corresponding moral rights. Finally, one might argue that some rights, such as the right to free speech, are both moral and legal rights.

Although Machan begins with the concept of moral rights, both the general argument and the specific argument depend on government enforcement of the right to occupational safety. As I will address shortly, one might argue that he should keep his focus on the moral right and avoid conflating it with the legal right. In one sense that claim is correct and accords with my interest in defending a moral right to occupational safety that employers should acknowledge and respect.

There are good reasons, however, not to quibble with Machan's conflation of moral and legal rights in this context. First, as Machan rightly points out, the right to occupational safety is one that is currently enforced by law and that enforcement has important implications for employers and employees. Second, Machan conceives of the right to occupational safety as a positive right. He writes of advocates of employee rights, "They hold that the employee- employer relationship involves special duties owed by employers to employees, creating (corollary) rights that governments ... should protect. Aside from negative rights, workers are owed respect of their positive rights to be treated with care and consideration.' 26 As a positive right, the right to occupational safety runs counter to one of the basic tenets of libertarianism that Machan follows. On the Nozickian grounds described earlier, libertarians reject positive rights because they necessarily infringe on the liberty of some person or set of persons.27 As Machan envisions it, the positive right to occupational safety entitles employees to safe working conditions and requires that employers provide those conditions. In this way, the right to occupational safety is quite different from the negative rights to life, liberty, and property that Machan endorses. As negative rights, they entitle one to freedom from others taking one's life, liberty, or property, but they do not require others to take steps to secure one's life, liberty, or property.

The second point is the more important reason for ignoring Machan's conflation of the moral and legal rights to occupational safety. He is correct in that the vast majority of those who support the moral right also support government enforcement when employers do not acknowledge and respect it. This does not mean that government should seek to enforce all moral rights. Some moral rights, such as that in the earlier example of the friend who breaks a promise, are not significant enough to justify government enforcement. Such exhaustive government enforcement of moral rights is undesirable for two reasons. First, governments simply do not have the resources to enforce all moral rights. Second, and moral importantly, doing so would constitute too great an invasion of citizens' lives. On the other hand, some moral rights, such as the right to freedom from slavery, are so significant that government enforcement is justified. Although the right to occupational safety is not on a par with the right to freedom from slavery, most supporters see it as significant enough to justify government enforcement.

Objections to the specific argument

A proponent of the right to occupational safety might object to the specific argument by rejecting premise 1. To do so, one must reject Mill's and Machan's anti-paternalism and argue that paternal- ism is morally justified in at least some instances. Many philosophers and ethicists may be willing to do just that since many have argued that paternalism is justified in a variety of contexts.28

Those of us who join Mill and Machan in opposing paternalism, however, are loath to take that approach. In general, we share Mill's doubts regarding the ability of people to be accurate and genuine in their judgments about others' good. Like Mill, we are concerned about just how far paternalistic intrusions will go. We worry that the intrusions will encroach on individuals' judgments about their 
own well-being. On the grounds that they are not in the good of the individuals who participate in them, those who accept paternalism often wish to abolish various activities that are important parts of many individuals' well-being. For example, just days before writing this, I had a somewhat serious bicycle accident. Even though it was my first accident after many years of cycling, several acquaintances have been quick to suggest that I should not cycle again. Although they do not have direct access to my mental states about cycling, they believe they can judge correctly that it is not in my good interest to take the risks associated with the activity. If they had the power to do so, some actually would prevent me from cycling again. In fact, these same people, if they had the power, would prevent everyone from cycling because they believe it is too dangerous an activity.

Cycling is just one activity among many that various people would like to abolish because, for one reason or another, they do not believe it is in the good of others to pursue them. This is the worry that many of us have about paternalism. Too often, people wish to take away activities that contribute to the well-being of those who pursue them. I know cycling comes with risks, but, for me, the rewards are worth those risks. Others should not be able to take away that part of my well-being. Likewise, skydiving is not an activity that contributes to my well-being in any way. In fact, given my particular set of fears, I do not understand how it can contribute to the well-being of anyone. I know, however, that many have quite different mental states about skydiving than I have. I should not prevent them from taking the risks associated with the activity merely because it does not contribute to my wellbeing and I am unable to understand how it contributes to theirs. It contributes to their well-being, and their well-being should be in their control.

Nevertheless, those of us who both oppose paternalism and favor the right to occupational safety face a significant challenge. We must provide a convincing objection to premise 2 by arguing that the right does not restrict the freedom of employees for the purposes of protecting them for their own good. To address whether this can be accomplished, I will examine two possible objections one might make against premise 2 that I will call the "moral right" and the "options" objections. I will argue that the first fails while the second succeeds.

The moral right objection:

One might object that Machan sees the right to occupational safety as paternalistic because he conflates the moral right to occupational safety with its legal recognition. It is the legal recognition of the right that is paternalistic, not the moral right itself. If we focus on the moral right itself rather than the legal enforcement of it, we can see that Machan has overstated what the moral right to occupational safety actually requires of employers. Even as a positive right, the moral right requires only that employers do not subject employees to dangerous working conditions without their consent. When fully informed employees agree to accept hazardous- duty pay, they grant their consent to the dangerous working conditions. Seen in this way, the moral right to occupational safety does not remove options from employees at all. If government intrudes and enforces the right in such a way that it removes options from employees, then government is being paternalistic in its legal recognition of the right. If government enforced the right by requiring employers to provide safe working conditions or obtain legitimate consent from employees to work in unsafe conditions, then the enforcement would not be paternalistic. If, on the other hand, government enforced the right by requiring employers to provide all employees with safe conditions, then the enforcement would be paternalistic. The moral right to occupational safety, so the objection would run, requires the former, not the latter. The right itself, as a moral right, is not paternalistic and, consequently, premise 2 is false.

Although the objection is based on a vision of the right to occupational safety that would produce circumstances with which Machan would be sympathetic, he likely would respond by claiming that the legal ramifications of the right cannot be ignored. It is hard to imagine legal recognition of the right that allows employers to make offers of hazardous-duty pay. Given that, Machan likely would argue that we must look at the legal ramifications of the right to determine its standing with respect to paternalism.

Another concern about this objection, albeit one with which Machan would be unsympathetic, is perhaps more important. We cannot overlook the problem of whether employees are in positions to 
grant legitimate consent if their employers propose options to work for hazardous-duty pay. In fact, it is quite likely that this problem gives rise to the legal recognition of the right to occupational safety that is the target of the objection. Although I cannot work out a full account of legitimate consent here, one salient feature of legitimate consent illustrates the problem. To consider that feature, set aside the positions of employees and consider the concept of consent in the abstract. In order to give legitimate consent in any matter, one must have a live option to do otherwise. Imagine one consents to $\mathrm{X}$ because another person is holding a gun to one's head. In a trivial sense, one could choose to accept the bullet rather than consent to $X$. That option, however, is not a live option for the vast majority of people. As William James writes, to be a live option it must make " ... some kind of appeal, however small, to your belief." 29 For an option to be live, one's belief system must be such that it allows one to consider the option a real possibility. Most of us do not have belief systems that allow us to consider choosing death in the described circumstances a real possibility. For this reason, one's consent to X is not legitimate.

This is not meant to imply, however, that anything less dire than a gun to one $=\mathrm{s}$ head is a live option. Assuming that his readers are ensconced in predominantly Christian societies, James writes, 'If I say to you: 'Be a theosophist or be a Mohammedan,' it is probably a dead option, because for you neither hypothesis is likely to be alive.' 30 Although James's assumptions about the belief systems of many ensconced in predominantly Christian societies likely are wrong, his example makes the central point about live options well. For one to see any $\mathrm{Y}$ as a live option, one must be able to consider it a real possibility. If James's assumptions about his readers were true, their belief systems would not allow them to consider the options he lays out as real possibilities.

The importance of live options is also illustrated in John Locke's and David Hume's debate over tacit consent.31 Locke derives legitimate government authority from the consent of the governed. Along the way, he argues that one often gives one's consent to the government tacitly. He writes, " ... every man, that hath any possessions, or enjoyment, of any part of the dominions of any government, doth hereby give his tacit consent ....' 32 For Locke, one gives tacit consent to a government by enjoying any of the benefits of that government including merely being within its territories. Hume rejects this view. He writes,

... implied consent can only have place where a man imagines that the matter depends on his choice.... Can we seriously say that a poor peasant or artisan has a free choice to leave his country, when he knows no foreign language or manners, and lives from day to day by the small wages which he acquires?33

To make his point, Hume lapses into an over- statement. We need only think of the poor people who enter the U.S. from Mexico to find con- temporary counterexamples to his claim. Moreover, undoubtedly it is true that even during Hume's time some poor peasants managed to leave the countries in which they lived. The point, however, is that doing so simply is not a live option for many people. Although it is true that some cross the border from Mexico, undoubtedly many would like to but cannot because of legal, financial, and other sorts of barriers. After all, many of those who cross the border do so illegally and face legal repercussions if they are caught. Civil disobedience against unjust laws aside, we should not conclude that people have live options when those options require violations of law. We should conclude, rather, that such options are not live because they are excluded by legitimate, legal barriers.34 Since leaving the territories of a government is not a live option for many people and, thus, merely being within those territories often is not truly a matter of choice, being within those territories cannot result in legitimate consent to government authority.

Neither consent to government authority nor tacit consent in general is at issue here, but Hume's position provides some relevant insight regarding live options. Often, employees feel that refusing to consent to their employers' wishes is not a live option. An unskilled employee may feel that rejecting an employer's offer is tantamount to asking to be fired. In most cases, as Werhane and Radin argue, employers are in stronger positions than are employees. This is especially true during tough economic periods with high unemployment. Even in good economic times, however, particular employees may feel pressured to agree to work for hazardous-duty pay because educational back- grounds, lack of experience, spotty work histories, or criminal records limit their employment opportunities. Although it does not involve hazardous- duty pay, a real scenario that my mother faced helps to illustrate this point. She married quite young, never completed high school, and did not work until she reached her 
thirties. During a recent holiday visit when the subject of business ethics arose, she recounted a time several years earlier when her employer asked her to do some personal errands for him that fell outside her job description. Despite feeling angered and believing that the employer's request was morally wrong, she did the errands. When I asked why she did them, she replied, "I didn't have a choice. I had to keep the job. Without a high school education I couldn't find another job. This town's not very big you know.' She had no live option to refuse because she knew that she had no other opportunities for work and her employer could easily find a replacement for her.

Examples like this highlight how duress bears on one's live options.35 Aristotle writes of one who chooses to throw cargo overboard during a storm in order to prevent the ship from sinking, “ $\ldots$ no one willingly throws cargo overboard, unconditionally, but anyone with any sense throws it overboard ... to save himself and the others."' 36 Under normal circumstances, keeping the cargo on board is not only a live option, it is perhaps the only live option. Under the duress of the storm, however, it is no longer a live option. One could keep it on board while the ship sinks, but, as Aristotle argues, any clear-thinking person would not see that as a live option. Employees often are in similar positions. My mother could have refused the employer's request and lost her job, but, because of the duress associated with her life circumstances, doing so was not a live option for her.

Globalization worsens this problem for many employees. With greater opportunities in other countries, the pool of prospective employees has been greatly enlarged for employers in many industries. Generally, these are industries that do not depend on a well-educated, high-tech labor force. As many people who have called a computer manufacturer's helpline can attest, however, even some high-tech positions are moving to other countries. The upshot is that in such industries, globalization has made it even easier for employers to reject employees' demands. They have more places to which they can turn for employees who are not in positions to make those demands.

Moreover, one important fact about capitalism strengthens employers' positions in most cases. Policymakers in capitalist societies often strive for full employment, but, as Porket writes, “ '... unemployment is a phenomenon which no modern economy can escape (as long as labour and the labour market are free) and without which no modern economy can thrive ...." 37 Essentially, the capitalist market system results in some level of unemployment. Attempts to drive the unemployment rate below whatever the market equilibrium rate is at the time, results in inflationary pressures. Carson, Thomas, and Hecht make the point in this way: "At all times, a natural rate of unemployment exists... It is the minimum unemployment level consistent with price stability. Any effort to lower the natural rate of joblessness would trigger inflationary wage and price pressures.' 38

The unemployment rate dictated by market equilibrium is a subject of considerable concern and de- bate among economists. For instance, many economists reject the term "natural rate." As Porket writes, " ... quite a few economists prefer a more neutral and accurate term, the one most frequently used being the 'non-accelerating inflation rate of unemployment' (NAIRU). While quite a few economists identify the non-accelerating rate of unemployment with the natural rate of unemployment, other economists have modified the concept of NAIRU.'” 39 For some economists, NAIRU simply is a more accurate term, while for others it is a theoretical departure from the term "'natural rate." 40 Although an in-depth analysis of economists' work on the subject is beyond the scope of this paper, note that there is consensus among economists regarding the central point. Samuelson and Nordhaus summarize the concern of economists in this way: "Many economists today think there is a natural rate of unemployment below which our economies can go only at the risk of spiraling inflation.... The search for a way to resolve the cruel dilemma of needing high unemployment to contain inflation continues to be one of the most pressing concerns of modern macroeconomics." 41

Hayek makes a striking point related to the "cruel dilemma" to which Samuelson and Nordhaus refer. In a section titled "The chief cause of unemployment," Hayek writes, "We know ... the general conditions in which what we call ... an 'equilibrium' will establish itself: but we never know the particular prices or wages that would exist if the market were to bring about such an equilibrium." 42 Hayek's point is that unemployment will deviate from the natural rate or NAIRU because of our inability to predict accurately at what wage rates market equilibrium will occur. Given that, at times, we will offer wage rates that produce unemployment rates higher than what equilibrium 
demands. Over time, Hayek argues, the market will move to equilibrium and the unemployment rate will move to the natural rate or NAIRU.

The upshot of this for my argument is that the natural rate of unemployment or NAIRU strengthens the position of employers with respect to employees. At any given time, there is some number of unemployed workers. Because there are other potential employees to which an employer can turn, rejecting an offer or demand of employer is less likely to be a live option for an employee than it would be if there were no unemployed workers.

There are some instances where rejecting employees' demands is not a live option for employers. These occur when employees possess some unique talents that are not found easily in the pool of unemployed or otherwise available workers. Imagine a hospital that employs a surgeon who is trained in a procedure that very few surgeons perform. Also, suppose that the hospital's prestige depends, at least in part, on providing that surgical procedure. If the surgeon made certain demands, rejecting them may not be a live option for the hospital. The cost, in terms of the hospital's prestige may be too great. In most cases, however, employers do not face that problem. Generally, employees' talents are found easily in the pool of unemployed or otherwise available workers.

At this point, one might object that I am under- valuing the extent of employees' live options. Most employees in the U.S., one might argue, have live options to find other work rather than agree to demands by their employers that they find unacceptable. Granted, they may have to do difficult things such as relocate, say, from a rural area to a city, but they have options they can consider real possibilities.

Although the objection forces serious evaluation of employees' options, it fails for two reasons. First, although it is true that many, perhaps most, employees in the U.S. have other live options to which they can turn if they do not like the offers or demands of their employers, those with poor educational backgrounds, little or no experience, spotty work histories, and criminal records often do not. This opens the door to countless opportunities for exploitation by employers and, thus, the ability of such employees to grant legitimate consent is questionable at best. Even if only some employees' consent is questionable, my position stands.

Second, it is not true in all cases that options requiring difficulties such as relocation are live options. Granted, relocation is a real possibility for many people. Moreover, for some, such as myself when I was admitted to graduate school, it is actually the fulfillment of dreams. Nevertheless, there are at least some people who have lifestyle and familial issues that simply do not allow them to consider relocation a real possibility. Imagine a poor, uneducated, unskilled worker with a large family who simply cannot take the entire family to a new location. We must question seriously the legitimacy of any consent such a worker grants to an employer's demand if the worker's only alternative is to relocate. The point is that options such as relocation often are extremely hard options that require major lifestyle and familial changes that some people cannot consider real possibilities.

The concern over whether employees are in a position to grant legitimate consent should not be pushed too far. To do so would be to fall into the very paternalism that I wish to join Mill and Machan in opposing. Nevertheless, it casts serious doubt, albeit not for reasons Machan would endorse, on the moral rights objection to premise 2. Because of that doubt, we should look elsewhere for a successful objection.

The options objection:

Machan describes the view of employee rights advocates that he rejects as follows:

Prior to government's energetic pro-labor interventions, safety, health, and related provisions for workers had been lacking. Only legally mandated workers' rights freed workers from their oppressive lot. Thus, workers must by law be provided with safety, health care, job security, retirement, and other vital benefits. 43

Although Machan did not intend it, his words point to a successful objection to premise 2 .

The difficulty for Machan lies in his view that the right to occupational safety restricts the freedom of employees. When considered from the perspective of the modified version of Machan's coal mining company example, it appears that the right does just that. Due to legal recognition of the right, employers cannot offer hazardous-duty pay to employees who are willing to work in unsafe 
conditions. This example, however, takes the right out of its historical context. When viewed in that historical context, the right actually has broadened rather than restricted the freedom of employees. The right and legal recognition of it played an important role in the emergence of the many opportunities employees have to work in safe conditions. Historical evidence shows that, without the right to occupational safety supported by legislation, the playing field was tilted in favor of employers in such a way that many employees lacked the necessary conditions to bring about positive changes in their working conditions in the way that Machan himself suggests that they should. Without a right to occupational safety sup- ported by legislation, too many employees would be destined to work in unsafe conditions without the options to work in safe conditions.

One need only consider the coal miners that Machan uses in his example to find evidence for this. Historically, when miners tried to organize so that they could cause changes in their working conditions such as improved safety, mine owners used violence and intimidation to block their efforts. Owners often hired armed agents to threaten and intimidate miners. Corbin writes of an actual event in West Virginia in 1920, "One hundred miners met at Roderfield, McDowell County, to form a local.... the county sheriff and a squad of Baldwin-Felts guards (who were also deputy sheriffs) arrived to break up the meeting and the local, a gun battle ensued, leaving four dead and four wounded." $44 \mathrm{He}$ also writes of coal mining companies' attitudes to- ward unions and their efforts to stop union activities:

The Mingo County operators were not about to surrender to the institution that they hated and that they claimed would cause the downfall of the United States. They brought in trainloads of strikebreakers from the South and New York and Chicago to run the mines and imported more and more guards to protect their plants and strikebreakers.45

Brit Hume makes clear the characteristics of the agents owners hired to confront the miners. He writes, "During a strike in 1920, the operators had imported a brigade of hired thugs from the infamous Baldwin-Felts Detective agency to evict miners from their company-owned houses. After they had done their dirty work ...." 46 H. B. Lee, Attorney General of West Virginia (1925-1933), writes of the agency,

This Agency ... was a ruthless, strikebreaking organization headed by William G. Baldwin and Thomas L. Felts - the two most feared and hated men in the mountains. For more than thirty years, its employees, called "Baldwin Thugs" and mine guards by the workers, had ruled the coal fields, fought strikes and strikers, and otherwise tyrannized over the miners.47

Lee points to the owners' use of the so-called "Yellow-Dog Contract"' as an especially intimidating tactic employed to prevent miners from organizing. He writes, "It acquired this scurrilous title because miners were compelled to sign it in order to secure or hold employment in the mines." $48 \mathrm{He}$ presents the following as a typical form of the contract:

\section{CONTRACT OF EMPLOYMENT}

I am employed by and work for the _____ Company, of _____, West Virginia, with the express understanding that I am not a member of the United Mine Workers of America, and will not become so while an employee of said ______ Company; that said company agrees to run an "Open Shop" while I am employed by said_________ Company. If at any time I want to join or become connected with the United Mine Workers of America, or any affiliated organization, I agree to withdraw from the employment of said Company, and I further agree that while I am in the employ of said Company that I will not make any efforts amongst its employees to bring about the unionization of said employees against the Company's wishes. I have either read the above or it has been read to me.
Dated this day of 19 (Signed) 49

Lee adds, "This little contract proved to be the most powerful weapon ever devised for excluding the miners' union from West Virginia's coal fields ....' 50

One might object, on behalf of Machan, that Lee exaggerates the effect of the yellow-dog contract. After all, one might argue, the miners were not compelled to sign. They could have refused employment in mines that required acceptance of the yellow-dog contract.

Such an argument, however, does not give adequate attention to the hardships that the miners faced, nor does it recognize how limited was the availability of alternative work for the miners. Lee describes the situation dramatically when he writes,

As a bitter aftermath of those strikes, Yellow-Dog Contracts, and injunctions, in the years between 1920 
and 1925, no fewer than 50,000 men, women, and children were evicted from their homes in southern West Virginia. They found shelter under cliffs, in tents, and in improvised shacks built by the union. Year after weary year they lived and starved in those unwholesome surroundings. Malnutrition and unsanitary conditions increased the death rate to appalling figures, especially among the children. But there was no relenting by the coal barons. To many of them their hungry, protesting workers were pariahs or outcasts, who had to be starved until hunger forced them to return to the service of their masters.

In the end, hunger won, and the workers slunk back to the mines with hearts filled with hate and minds embittered by the memory of the wrongs they had suffered.51

The evictions to which both Hume and Lee refer point to another important aspect of the intimidation miners faced. Because many mine owners actually owned the entire towns in which they operated, they were able to use various forms of economic intimidation. Foner writes,

Those attempting to organize a mine workers union in West Virginia faced daunting obstacles, not the least the tight control of local communities and state government by coal operators and railroad companies. In West Virginia, far more miners (over ninety percent) lived in towns where housing was owned by the companies than in any other state. On any given day, their homes were subject to unannounced searches by company agents, and they were often paid in scrip redeemable only at company stores.52

Even though he likely would be unsympathetic to the portrait of the miners' working and living conditions that I have painted, Fishback writes,

In one sense, making housing contingent on employment was a device to control workers and prevent collective action. The clause raised the expected costs of complaining if a miner thought he might be fired. If the worker was fired, he not only incurred the costs of finding a new job but also the costs of finding new housing. 53

It is striking that Fishback acknowledges this point since he argues that the reasons for companyowned housing are more complex than those suggested by Corbin, Lee, and Foner. He also argues that owners bear less of the responsibility for the violent confrontations with miners than writers generally attribute to them.54

Many operators also used the threat of the military draft against miners during World War I. Corbin writes that some companies used “ ... a 'slacker board,' a large blackboard that posted the amount of coal each worker mined .... At the end of a certain amount of time, the miners producing the lowest amounts of coal were fired, thus losing their draft exemptions.' 55 Without legal recognition of their rights, there was little miners could do to end the threats and intimidation they faced. It is no surprise that incidents of violence and intimidation led to infamous episodes such as the 1920 Matewan Massacre that resulted in the death of the town's mayor, two miners, and seven armed guards hired by the mine owner.56

Circumstances such as those faced by the coal miners who sought to organize and struggle for improvements in their working conditions demonstrate that too often employees lack the necessary conditions to bring about such changes. The coal miners needed government intervention so that they could have live options to do something about their working conditions. Without it, they faced force, intimidation, coercion, and duress that prevented them from taking steps to bring about the positive changes they so desperately needed. In this way, government intervention actually enhanced employees' options rather than, as Machan believes, reduced them. The government intervention was freedom-enhancing rather than, as Machan believes, paternalistic.

This does not mean, however, that employees always need the help of government intervention in order to achieve their desired goals. In many cases, such as when employees possess unique talents that are hard to find in other potential employees, they can succeed quite well on their own. Also, it does not mean that all positive changes in workplace safety are the results of the right to occupational safety and its supporting legislation. Clearly, many improvements in workplace safety are the result of technological innovations. One need only think of the development of now commonplace items such as safety glasses, safety belts, and hardhats to find technological innovations that make workplaces safer. Nevertheless, the historical evidence demonstrates how many employees need the right to occupational safety and its supporting legislation so that they are in positions where they can take the steps that are necessary to bring about positive changes in their working conditions.

At this point, one might object to the inference that I draw from this historical evidence by arguing that if employees are willing to sacrifice some income for additional safety measures, then 
there would be no reason for employers not to provide those conditions. In fact, one might argue that the violence to which I have referred was the result of employees not being willing to make such sacrifices for the things that they wanted.

This argument is less than convincing. Although many miners were far from innocent with respect to the violent episodes I have described, the historical evidence demonstrates the extreme steps owners took to fight attempts by the miners to organize. Such organization, however, is exactly what the miners would have needed in order to determine whether they should accept income reductions in return for additional safety measures. To make rational decisions about particular measures, they would need to discuss what could be gained by them and whether they could bear the income reductions that would be required. So, the kind of agreement the objector envisions requires the very organization that the owners tried to prevent.

This point about owners' efforts to stop miners from organizing bears directly on Machan's position regarding the options of workers who are unhappy with their working conditions. Recall that Machan claims that one option for such workers is to " ... organize into a group and insist on various terms not in the offing ....' $57 \mathrm{He}$, too, assumes that the miners had the ability to organize even though the owners impeded it with violence and intimidation.

Given the impact that owners' efforts had on the options of employees, Machan's view that the right to occupational safety reduces the freedom of employees is mistaken and premise 2 of the specific argument is false. It is true that the right removes one option from employees. In that sense, the right is restrictive. Employees cannot opt to work for hazardous-duty pay. This restriction and lost option, however, does not reduce employees' freedom. In fact, we cannot evaluate their freedom by looking merely at this one lost option. We must consider the host of options to work in safe conditions that the right has helped to provide employees. The additional options are valuable options and the right helps to maximize them. In this way, the right enhances employees' freedom. Thus, the right is far from paternalistic. It has enhanced the freedom of employees by maximizing their valuable options.

In this way, the right to occupational safety is significantly similar to an exercise program. A true commitment to a program means that one devotes blocks of time to exercise. In so doing, one loses the option to do something else with that time. The loss is especially evident when one is an athlete with a strict coach. This does not mean, however, that an exercise program is paternalistic, nor does it mean that the program actually reduces one's freedom. Countless people can attest that exercise programs actually free them by creating new, valuable options. By making them more capable of performing certain tasks and athletic feats, it enables them to do things that they could not do before beginning their pro- grams. For many, this produces greater efficiency at work. For others, it allows them to pursue certain recreational activities that were once beyond their abilities. Still others gain in both ways. Like one who reaps the benefits of an exercise program despite losing the option to do other things during the time devoted to exercise, employees gain options from the right to occupational safety despite losing the option to work for hazardous-duty pay. Those options enhance their freedom.

The similarities between the right to occupational safety and an exercise program, however, are limited. Generally, one freely chooses to start an exercise program, while law mandates the right to occupational safety. Thus, the options removed by an exercise program are removed by one's own choice, while the options removed by the right to occupational safety are removed by government mandates. Nevertheless, there are some cases where the similarities are stronger. For example, a football player who enters the NFL draft ultimately is subject to an exercise program mandated by the coach of the team that drafts him. This is not that different from an employee who votes in elections and then is subject to the right to occupational safety that is mandated by the government she or he helped to elect. Regardless of how strong the similarities in a particular instance, however, the exercise program example demonstrates that there are cases where losing some options creates others, and, thereby, increases freedom.

Concerns about economic growth and efficiency:

I will close by addressing two possible objections to my argument that are based on concerns about 
economic growth and efficiency. Both objections raise worries that one who holds my view or a similar view cannot ignore.

\section{Objection 1:}

One might point out that to the extent that regulations enforcing the right to occupational safety increase costs for employers, employees likely will suffer job losses in at least three ways. First, employers who must bear the burden of purchasing expensive safety equipment are likely to turn to cheaper labor in other countries where they are not required to expend the funds on safety equipment. Second, the same employers might turn to more mechanized and automated methods of accomplishing their goals that require fewer employees. For example, mining companies might turn to strip- mining that, while more harmful to the environment, requires fewer employees than does traditional mining. Third, foreign competitors that face lower labor and safety costs will capture more markets. U.S. employers will respond by reducing their labor forces. In these ways, one might argue, employees suffer from a government-enforced right to occupational safety.

Although these are important worries, they do not defeat my argument. The first and third scenarios depend on the fact that employees in other countries are not afforded the same rights and protections as U.S. employees. To the extent that this is true in the actual world, there is not much that I can offer in response. The important point, however, is that my argument is not meant to apply only to U.S. employees. I believe all employees, regardless of the countries of which they are citizens, have a moral right to occupational safety. If necessary, that right should be protected by government regulation. If the right were acknowledged and respected for all employees around the globe, the objector's worry would not arise in the ways described by the first and third scenarios. Any lower costs found in other countries would be the result of factors other than the right to occupational safety.

The second scenario presents two distinct challenges. The first arises in those instances, such as mining companies turning strip-mining, where employers turn to more mechanized and automated methods that are more harmful to the environment or other goods that we, as a society, value. In such cases, when necessary, government regulation should be used to protect the environment and those others goods.58 When done wisely, the possibility raised by the scenario would be excluded for the instances described.

The second challenge arises in those instances where employers turn to more mechanized and automated methods that do not harm other goods we seek to protect. In such cases, the possibility of job losses simply is a burden that employees must bear. If no goods that we value are threatened, we cannot stand in the way of technological innovation. The important point, however, is that this is not a worry that arises because of the right to occupational safety. With or without it, employees must face the possibility that their jobs could, at any time, be lost to technological innovation. Even college professors must worry about the impact of technological developments that allow new modes of education such as distance learning.

Objection 2:

One might object that I need to take more seriously the connection between economic growth and increases in safety to which I alluded earlier. If it is true that the vast majority of improvements in safety result from technological innovations, we need to make the marketplace friendly to such innovation. Government regulation stifles such innovation by placing undue burdens on businesses. If I truly care about the safety of employees, so the objection might run, then I should abandon my stance that government should enforce a right to occupational safety. In the long-run, employees will be safer if we allow the market to be free so that economic growth will spawn more technological innovations.

How at odds my argument is with the objector's view depends on how close the objector sees the connection between regulation and economic growth. I agree with the objector's point that we should not have stifling, government regulation that is an undue impediment to economic growth and technological innovation. If the reviewer holds the view that any government regulation whatsoever is an undue impediment to economic growth and technological innovation, however, then the reviewer holds a libertarian view that I reject. It is simply beyond what I can do here to explain and provide my 
objections to the various tenets of libertarianism. All I can offer is to point out that U.S. society has seen tremendous economic growth and countless technological innovations during the era in which we have implemented government regulations.

If, on the other hand, the objector's view is the more modest claim that the right to occupational safety, as it is currently enforced by law, has proven to be an undue impediment to economic growth and technological innovation, then my response is quite different. If that is the reviewer's position, then I am sympathetic to the worry and I share the belief that we should guard against stifling government regulation. To the extent that government has regulated occupational safety in ways that have been undue impediments to economic growth and technological innovation, the regulation should be changed so that it does not impose such impediments .59 It does not follow, however, that no regulation should be imposed. Regulation that requires unwilling employers to acknowledge and respect employees' moral right to occupational safety, but does not produce undue impediments to economic growth and technological innovation, still is justified.

\title{
Concluding remarks:
}

If I am correct, then, the right to occupational safety actually frees employees rather than subjects them to paternalism as Machan suggests. Nevertheless, we must take Machan's specific argument more seriously than we have so far. Because business ethicists have focused on his general argument, we have not paid enough attention to his argument against the right to occupational safety that stands or falls independently of the general argument. That independent argument poses a significant challenge to those of us who both oppose paternalism and support the right to occupational safety. I hope that I have met that challenge here. If not, I hope others who also reject paternalism and support the right to occupational safety will join me in trying to meet the challenge.

\author{
Notes \\ See Machan (1987). \\ Some of those who have argued either for or against employment at will are: DesJardins (1985), \\ DesJardins and McCall (1985), Epstein (1984), Freed and Polsby (1989), Hiley (1985), Larson (1986-87), \\ Maitland (1989), McCall (2003), Phillips (1992), Posner (1989), Power (1983), Radin and Werhane (2003), Sass \\ (1985), Werhane (1983 and 1988), and Werhane and Radin (1996). \\ 3 For his classic defense of anti-paternalism, see Mill $(1859 ; 1978)$. For contemporary essays on that work, \\ see Dworkin (1997). \\ 4 Accordingly, Machan believes that governments should enforce only the rights to life, liberty, and \\ property. To enforce other types of moral rights, such as employee rights, would be to enforce nonexistent rights. \\ Machan (1987, pp. 45-46). \\ Machan (1987, p. 46). \\ Nozick (1974, p. 163). \\ See Radin and Werhane (2003), Werhane (1983 and 1988), and Werhane and Radin (1996). \\ Radin and Werhane (2003, p. 115). \\ See Werhane and Radin (1996) and McCall (2003). \\ See Faden and Beauchamp (1988), Sass (1986), and Superson (1983). \\ Machan (1987, p. 48). \\ Machan (1987, p. 49). \\ Neither Machan nor his opponents believe that an employee who has agreed to do a dangerous job such \\ as a police officer or firefighter can refuse to do the job any time it becomes unsafe. Such jobs are inherently \\ dangerous. Machan's opponents do believe, however, that employees should be able to refuse hazardous work \\ without fear of dismissal when employers provide conditions that make the work more dangerous than is \\ necessary. Machan does not hold that view. \\ 15 Machan (1987, p. 47). \\ 16 For this reason, the paternalism at issue in the remainder of this paper will be paternalism directed to- \\ ward adults. \\ 17 Machan (1987, p. 48). \\ 18 Machan (1987, pp. 49-50). \\ 19 Machan (1987, p. 50). \\ $20 \quad$ Mill (1859; 1978, p. 74).
}


$21 \quad$ I am indebted to an anonymous reviewer who cited Butler.

22 Butler $(1726 ; 1983$, p. 20).

23 Butler (1726; 1983, p. 21).

$24 \quad$ Mill $(1859 ; 1978$, p. 74).

25 Butler (1726; 1983, p. 21).

26 Machan (1987, p. 46).

27 I will not try to defend Machan's rejection of positive rights since it is one of the tenets of libertarianism I reject.

28 Some of them are: Archard (1993 and 1994), Arneson (1989), Carter (1977), Cohen (1986), Dworkin

(1972), Ebejer and Morden (1988), Hodson (1977), Hoffmaster (1980), Jorgensen (2000), Kleinig (1984), Lee

(1981), Rainbolt (1989), Strong (1984), and VanDeVeer (1980).

29 James (1896; 1984, p. 309).

$30 \quad$ James (1896; 1984, p. 309).

31 See Locke $(1690 ; 1980,63-65)$ and Hume 1748; 1948, 363-364). For examinations of tacit consent in contemporary philosophy literature, see Bennett (1979) and Simmons (1976).

$32 \quad$ Locke $(1690 ; 1980$, p. 64).

33 Hume $(1748 ; 1948$, p. 363).

34 This is not the place to explore whether all features of U.S. immigration laws are just, so I am assuming here merely that a person who wishes to cross the border from Mexico faces some legal barriers that, at least in part, are legitimate. Even if that is not true, however, such a person still faces legal repercussions if caught.

35 I am indebted to an anonymous reviewer who suggested the importance of Aristotle's examination of choice under duress for my purposes here.

36 Aristotle (1985, p. 54).

37 Porket (1995, p. 19).

38 Carson, Thomas, and Hecht (2002, p. 115).

39 Porket (1995, p. 19). A

40 As examples of how economists differ in their use of terms, Minford and Peel (2002) use the term "natural rate", and Layard, Nickell, and Jackman (1994) use the term "NAIRU."

41 Samuelson and Nordhaus (1992, p. 616).

42 Hayek (1975, p. 33).

43 Machan (1987, p. 47).

44 Corbin (1981, p. 196).

45 Corbin (1981, p. 202).

46 Hume (1971, p. 113).

$47 \quad$ Lee $(1969$, p. 53).

$48 \quad$ Lee $(1969$, p. 78$)$.

49 Lee $(1969$, p. 78).

$50 \quad$ Lee $(1969$, p. 79).

$51 \quad$ Lee $(1969$, p. 83).

$52 \quad$ Foner (1995, p. 204).

53 Fishback (1996, p. 214).

54 Long (1996) explains and rejects Fishback's account. On p. 363, she claims that he relies on a “... fallacious notion of the coal miner's violent nature ....'

$55 \quad$ Corbin (1981, p. 186).

56 Sayles (1987) is a film dramatization of the massacre and the events leading to it. Foner (1995) provides an historian's view of the film and the massacre. For a more complete account of the struggles of West Virginia coal miners, including the Matewan Massacre, see Corbin (1981).

$57 \quad$ Machan (1987, p. 49).

58 An examination of the extent of such regulation, what goods it should protect, and when and how it should be utilized is beyond what I can accomplish in this paper.

59 An examination of whether and in what ways such regulation has produced undue impediments to economic growth and technological innovation is be- yond what I can accomplish in this paper.

\section{References}

Archard, D.: 1993, 'Self-Justifying Paternalism', Journal of Value Inquiry 27, 341-352.

Archard, D.: 1994, 'For Our Own Good', Australasian Journal of Philosophy 72, 283-293.

Aristotle: 1985, 'Nicomachean Ethics', tr. by T. Irwin (Hackett Publishing Company, Indianapolis).

Arneson, R. J.: 1989, 'Paternalism, Utility and Fairness', Revue Internationale de Philosophie 43, 409-437. 
Bennett, J. G.: 1979, 'A Note on Locke's Theory of Tacit Consent', Philosophical Review 88, 224-234.

Butler, J.: 1726; 1983, 'Five Sermons', S. L. Darwall (ed.), (Hackett Publishing Company, Indianapolis). Carson, R. B., W. L. Thomas and J. Hecht: 2002, Macroeconomic Issues Today. 7 (M. E. Sharpe Armonk, New York).

Carter, R.: 1977, 'Justifying Paternalism', Canadian Journal of Philosophy 7, 133-145.

Cohen, E. D.: 1986, 'Paternalism That Does Not Restrict Individuality: Criteria and Applications', Social Theory and Practice 12, 309-335.

Corbin, D. A.: 1981, Life, Work, and Rebellion in the Coal Fields (University of Illinois Press, Urbana).

DesJardins, J.: 1985, 'Fairness and Employment-At-Will', Journal of Social Philosophy 16, 31-38.

DesJardins, J. R. and J. J. McCall: 1985, ‘A Defense of Employee Rights', Journal of Business Ethics 4, 367-

376.

Dworkin, G.: 1972, 'Paternalism', Monist 56, 64-84.

Dworkin, G.: 1997, Mill's on Liberty: Critical Essays (Rowman \& Littlefield, Lanham, MD).

Ebejer, J. M. and M. J. Morden: 1988, 'Paternalism in the

Marketplace: Should a Salesman Be His Buyer's Keeper', Journal of Business Ethics 7, 337-339.

Epstein, R. A.: 1984, 'In Defense of the Contract at Will', University of Chicago Law Review 51, 947-982.

Faden, R. R. and T. L. Beauchamp: 1988, 'The Right to Risk Information and the Right to Refuse Health

Hazards in the Workplace', in T. L. Beauchamp and N. E. Bowie (eds), Ethical Theory and Business 3rd edition, (Prentice Hall, Englewood Cliffs, NJ), pp. 226-233.

Fishback, P. V .: 1996, 'The Miner's Work Environment: Safety and Company Towns in the Early 1900 s', in J. H. M. Laslett (ed), The United Mine Workers of America: A Model of Industrial Solidarity? (The Pennsylvania State University Press, University Park, PA), pp. 201-223.

Foner, E.: 1995, 'Matewan', in T. Mico, J. Miller-Monzon and D. Rubel (eds), Past Imperfect: History

According to the Movies (Henry Holt, New York), pp. 204-207.

Freed, M. G. and D. D. Polsby: 1989, 'Just Cause for Termination Rules and Economic Efficiency', Emory Law Journal 38, 1097-1144.

Hayek, F. A.: (1975, Full Employment at Any Price? (Institute of Economic Affairs, London).

Hiley, D. R.: 1985, 'Employee Rights and the Doctrine of At Will Employment', Business \& Professional Ethics

Journal 4, 1-10.

Hodson, J. D.: 1977, 'The Principle of Paternalism', American Philosophical Quarterly 14, 61-69.

Hoffmaster, B.: 1980, 'Physicians, Patients, and Paternalism', Values and Ethics in Health Care 5, 189-202.

Hume, B.: 1971, Death and the Mines: Rebellion and Murder in the United Mine Workers (Grossman Publishers, New York).

Hume, D.: 1748; 1948, 'Of the Original Contract', in H. D. Aiken (ed), Hume's Moral and Political Philosophy (Macmillan Publishing Company, New York), pp. 356-372.

James, W.: 1896; 1984, 'The Will to Believe', in B. W. Wilshire (ed), William James: The Essential Writings (State University of New York Press, Albany), pp. 309-325.

Jorgensen, H. K.: 2000, 'Paternalism, Surrogacy, and Exploitation', Kennedy Institute of Ethics Journal 10, 39_ 58.

Kleinig, J.: 1984, Paternalism (Rowman \& Allenheld, Totowa, NJ).

Larson, L. S.: 1986-87, 'Why We Should Not Abandon the Presumption That Employment is Terminable AtWill', Idaho Law Review 23, 219-253.

Layard, R., S. Nickell and R. Jackman: 1994, The Unemployment Crisis. (Oxford University Pres, Oxford). Lee, H. B.: 1969, Bloodletting in Appalachia: The Story of West Virginia's Four Major Mine Wars and Other Thrilling Incidents of its Coal Fields (West Virginia University, Morgantown).

Lee, S.: 1981, 'On the Justification of Paternalism', Social Theory and Practice 7, 193-204.

Locke, J.: 1690; 1980. 'Second Treatise of Government', C. B. Macpherson (ed.), (Hackett Publishing Company, Indianapolis).

Long, P.: 1996, 'The 1913-1914 Colorado Fuel and Iron Strike, with Reflections on the Causes of Coal-Strike Violence', in J. H. M. Laslett (ed), The United Mine Workers of America: A Model of Industrial Solidarity? (The Pennsylvania State University Press, University Park, PA), pp. 345-370.

Machan, T. R.: 1987, 'Human Rights, Workers' Rights, and the 'Right' to Occupational Safety', in G. Ezorsky (ed), Moral Rights in the Workplace (State University of New York Press, Albany), pp. 45-50.

Maitland, I.: 1989, 'Rights in the Workplace: A Nozickian Argument', Journal of Business Ethics 8, 951-954.

McCall, J. J.: 2003, ‘A Defense of Just Cause Dismissal Rules', Business Ethics Quarterly 13, 151-175.

Mill, J. S.: 1859, 1978. 'On Liberty’, in E. Rapaport (ed.), (Hackett Publishing Company, Indianapolis).

Minford, P. and D. Peel: 2002, Advanced Macroeconomics: A Primer. (Edward Elgar Publishing, Cheltenham, UK).

Nozick, R.: 1974, Anarchy, State, and Utopia (Basic Books, New York). 
Phillips, M. J.: 1992, 'Toward a Middle Way in the Polarized Debate over Employment at Will', American Business Law Journal 30, 441-483.

Porket, J. L.: 1995, Unemployment in Capitalist, Communist and Post-Communist Economies (St Martin's Press, Oxford).

Posner, R. A.: 1989, 'Hegel and Employment at Will: A Comment', Cardozo Law Review 10, 1625-1636.

Power, R. W.: 1983, 'A Defense of the Employment at Will Rule, Saint Louis University Law Journal 27, 881899.

Radin, T. J. and P. H. Werhane: 2003, 'Employment- At-Will, Employee Rights, and Future Directions for Employment', Business Ethics Quarterly 13, 113-130.

Rainbolt, G. W.: 1989, 'Prescription Drug Laws: Justified Hard Paternalism', Bioethics 3, 45-58.

Samuelson, P. A. and W. D. Nordhaus: 1992, Economics. 14 (McGraw-Hill, New York).

Sass, R.: 1985, 'Commentary on Hiley's "Employee Rights and the Doctrine of At Will Employment', ,

Business \& Professional Ethics Journal 4, 11-16.

Sass, R.: 1986, 'The Workers' Right to Know, Participate and Refuse Hazardous Work: A Manifesto Right', Journal of Business Ethics 5, 129-136.

Sayles, J., dir.: 1987, Matewan, a film originally released by Cinecom International Films.

Simmons, A. J.: 1976, 'Tacit Consent and Political Obligation', Philosophy \& Public Affairs 5, 274-291. Strong, C.: 1984, 'Paternalism in the Neonatal Intensive Care Unit', Theoretical Medicine 5, 105-116.

Superson, A. M.: 1983, 'The Employer-Employee Relationship and the Right to Know', Business \& Professional Ethics Journal 3, 45-58.

VanDe Veer, D.: 1980, 'Autonomy Respecting Paternalism', Social Theory and Practice 6, 187-208.

Werhane, P. H.: 1983, 'Accountability and Employee Rights', International Journal of Applied Philosophy 1, 15-26.

Werhane, P. H.: 1988, 'Employee and Employer Rights in an Institutional Context', in T. L. Beauchamp and N. E. Bowie (eds), Ethical Theory and Business 3rd edition, (Prentice Hall, Englewood Cliffs, NJ), pp. $267-271$. Werhane, P. H. and T. J. Radin: 1996, 'Employment at Will and Due Process', in T. Donaldson and P. H. Werhane (eds), Ethical Issues in Business: A Philosophical Approach 5th edition, (Prentice Hall, Upper Saddle River, NJ), pp. 364-374.

Earl W. Spurgin

Department of Philosophy

John Carroll University

20700 North Park Blvd. University Heights, Ohio, 44118, U.S.A.

E-mail: espurgin@jcu.edu 